Nikolai Genov

School for Advanced Social Studies, Slovenia

\title{
STRUCTURAL OPTIONS AND CONSTRAINTS FOR UPGRADING ORGANIZATIONAL RATIONALITY CASE OF THE EUROZONE CRISIS
}

\section{THE EUROZONE AT RISK}

The integration of states and societies in the European Union is the most advanced regional cooperation worldwide. In other parts of the world the achievements of European integration are usually seen as a pattern to be followed (Haller 2012). However, the European Union faces a challenge which is seen as the most intensive one in its history. Several member states of the common currency area are deeply indebted. Their potential financial default could threaten the European Monetary Union. In broader terms, the whole area of the European Union is marked by low economic growth, fiscal problems and weakened banking sector. These structural threats to the European integration are being amplified by difficulties of policy-makers to act fast and decisively on the basis of European solidarity.

It is striking to note that the conceptual framework of the analyses of the Eurozone crisis (Riet 2010; Beblavý 2011; Arestis and Sawyer 2012) is meager or missing at all. Could the analytical concept of risk help resolving this task? Risk is hereafter understood as probability of dysfunctional effects of processes on social systems (Genov 1999: 35-36). The achievement-oriented and largely secularized modern societies have developed a specific culture of risk. It is based on the rationalized perception and assessment of risk factors as well as on the tradition of rationalized risk management. This culture of risk and its institutional frameworks are dominated by calculations of risk's intensity and by accountability for man-made risks (Renn 2008). One may assume that this concept could be instrumental for transparent coverage of the dynamic situations related to the Eurozone crisis.

First, the concept of risk could be expected to allow the cognitive reduction of complexity by disentangling risk factors and effects. Second, the differentiated concept of risk could make it possible to clearly identify actors involved 
in situations of risk perception, assessment and management. Third, when focusing on the conditions of a risk, one may ask about social relations fostering adequate perception, assessment and management of risk, or blocking them. Fourth, the continuity of risk perception, assessment and management closely corresponds to stages of social action as process. Fifth, one may attempt a systematic qualitative and quantitative assessment of potential risk factors and their negative impacts on systems of social interaction. Sixth, the risk concept might allow for a comprehensive operationalization of risk factors, approaches to risk management and its effects.

What is the descriptive, explanatory and prognostic potential of the above conceptualizations for the analysis of the European sovereign debt crisis?

\section{THE HANDLING OF THE EUROZONE CRISIS AS RISK MANAGEMENT}

\section{Identification of risk}

According to the Treaty of Maastricht (1992) national finances remained in the jurisdiction of the EU member states. In the course of the implementation of the Treaty it became a public secret that the governments of some members of the Eurozone were regularly spending more than their budget revenues could allow. The difference has been covered by borrowings. The global financial and economic crisis after 2008 sharpened the sensitivity to the effects of the bankruptcy of large banks and companies. The awareness rose about potentially devastating consequences of a sovereign debt crisis of states in the Eurozone. More precisely, the potential default of the Greek state could have domino effects by destabilizing the lender countries and accelerating the default of other states in the Eurozone. Therefore, the accumulation of risky sovereign debts could no more be acceptable.

\section{Search for causes of the risk}

The typical explanation of the sovereign debt crisis underlines the lax policies of public spending. This explanation is simplistic. Undoubtedly, some EU governments have bought public peace by overspending. The destructive effects of these policies became obvious in the context of economic decline due to the global crisis. But the causes of the sovereign debt crisis are more complex and have accumulated long before the crisis. Some of the causes are domestic. Clientelist party politics lead to pathological growth of state administration 
and the related budget spending in Greece. However, the major causes of the sovereign debt crisis have to be searched in the different competitiveness of national economies in the Eurozone. The account deficits of the less competitive national economies have been typically balanced by borrowings from institutions in the Eurozone countries running current account surpluses. This practice receives specific relevance in the context of the European integration. The member states of the Eurozone cannot reduce their indebtedness by instigating domestic inflation. Thus, accumulated sovereign debts became a major risk for the stability of the Eurozone.

The Treaty of Maastricht did not ameliorate the situation by introducing regulation mechanisms for the financial exchange in the Eurozone. Therefore, the Treaty was designed and implemented in deviation from the ideal of an optimum currency area (Mundell 1968: 177f.). No balancing between countries running account surplus and deficit as well as no common wages and taxation policies were introduced. As a result, Greek political parties were able to corrupt their clienteles by offering them jobs in the expanding state administration. Politicians bought political support by generous salary and pension policies. In the same time, Greek governments have tolerated notorious inefficiency of taxation (Manolopoulos 2011: 81f.).

Greek economy has been mismanaged under the administrative umbrella of the Union and by misusing EU subsidies. This became possible due to the neoliberal philosophy of the Treaty of Maastricht. The stress on the advantages of economic integration was not matched in it by considerations about political regulation of the economic processes (Busch and Hirschel 2011). The reason for this one-sided integration strategy was the need to avoid political blocking of the economic integration. But the disparity between the appeals for stricter control on national budgets and the opposition against the deepening of the European political integration could not be viable any more.

\section{Risk assessment}

It took long to achieve a consensual assessment of the risks related to the looming default of Greek finances. The outcome of the deliberations was the conclusion that the Greek case is a test for the viability of the European Monetary Union. Thus, the default of the Greek state was defined as an immediate threat to the organization. The management of the risks related to this specific sovereign debt crisis had to be regarded as collective responsibility and organized correspondingly. The argument was that the denial of support or the insufficient support to 
the Greek state would undermine the trust of investors in the Eurozone and could provoke a chain reaction ("contagion") of defaults in other countries there. This intensity of risks could not be acceptable.

Some analysts argued that the option of orderly default should be immediately implemented by re-introducing and devaluating the Greek drachma. This would make the prospects for stabilization of the Greek state finances a matter of foreseeable future. The counter-argument was that the lenders would lose large portions of their credits and this would provoke imbalances in the international financial system. What followed could be at least partly explained by the latter consideration. Two strategic alternatives became obvious. The first was the coordinated action for financial support to the Greek government requiring changes of the Maastricht organizational construction. The second was the radical questioning of this construction with all consequences for institutions, countries, the European Union and possibly the world (Lorca-Susino 2010: $183 \mathrm{f}$; Lynn 2010: 223f.).

\section{Reactions to the risk (risk management)}

Contrary to the neo-liberal spirit of the Treaty of Maastricht, interventionist policies of the Union became unavoidable due to the critical circumstances. Change management became management of intensive risks. The long deliberations at national and EU level demonstrated the difficulties in balancing national interests (Bastasin 2012). The deliberations and negotiations brought about an outcome. In May 2010 the European Financial Stability Facility was established. Together with the International Monetary Fund the Eurozone countries offered a rescue package to Greece after the country's government debt was rated as junk. Bailout was approved for Ireland followed by a rescue package for Portugal. In parallel, the European Central Bank decided to support the Greek government by buying its bonds despite their junk status. The same procedure applied to Irish and Portuguese governmental bonds.

The EU support to the Greek finances became possible after the Greek government announced far-reaching austerity measures. They provoked riots. The major political argument of the rioters was that the country has given up its budgetary sovereignty. The argument could not be questioned. The background of the support was the move towards tighter budgetary control of EU states by EU institutions. This implied deepening of the economic and political integration in the Eurozone and thus in the European Union. The decision taken in July 2011 to offer credit lines to Eurozone countries having difficulties on the financial markets became a milestone in this direction. Thus, the deepening 
of the European integration became acceptable under the critical conditions. Meanwhile it became clear that the Greek state would need a second and later third package of support. The condition to provide them was the implementation of second and third waves of austerity measures in Greece. Another condition was the deal of the Greek government with private lenders for reducing the value of the Greek governmental debt to them.

Along this line of actions, the European Union expanded its capacities to handle critical financial situations in member states. The temporary European Financial Stability Facility (EFSF) was replaced by the permanent European Stability Mechanism. The most radical step in the direction of deepening the economic and political integration in the EU was taken in December 2011. The European Council - with the exception of the United Kingdom - took path breaking decisions about stricter financial control by the EU on the budget policies of the member states.

\section{Evaluation of risk management}

The need to intervene into the financial processes in contradiction with the Treaty on the Functioning of the European Union is a clear indication for the organizational vulnerability of the Union (Lorca-Susino 2010: 111f.). The long delay, the hesitations and the various forms of open or hidden opposition in the course of the implementation of the rescue measures for Greece made the problems of the European integration manifest. The repeated references to solidarity notwithstanding, the decisions for rescue measures were primarily guided by concerns that there could be greater losses in case that the support would not be offered.

Experts continue to be divided in their opinions about the rescue measures and their efficiency. Some of the experts still believe that a controlled default of the Greek state would be the best handling of the risk situation. Other experts insist on the point that the financial support to the Greek state had come too late and was counterproductive since it was conditioned on strong austerity measures. They hinder the very much needed economic growth in Greece, in the Eurozone and in the European Union as a whole (Andini and Cabral 2012). The support provided to the Greek government by public agencies raised the delicate issue of the public-private partnerships. The arrangement involving the private institutions into the rescue measures is a positive outcome of the risk management. But the most important consequence of the measures taken in support to Greek economy is definitely the establishment of the permanent European Stability Mechanism. Its task is to closely supervise the financial 
policies of the EU member states. Thus, the handling of the Greek sovereign debt crisis became the turning point in the upgrading the organizational rationality of the European Union. This is a development which is not the best wish of some EU member states. The crucial problem is the tremendous amount of funding needed for ESM to be efficient in supporting large European economies. The issue will remain on the agenda of the European Union in the long run (De Grauwe 2011).

If the issuing of euro-bonds could be the long-term solution of the problems of the Eurozone - this is still to be clarified (Delpla and von Weizsäcker 2011). The key point in the debates concerns the organizational framework of the issuing and use of the bonds. Whatever financial instruments to be invented and applied, this could not be efficiently done without an institution which would play the role of European Ministry of Finance. It will have to implement the control on state budgets, fiscal policies and international competitiveness of the EU member states. The functioning of this mechanism is expected to become a crucial step forward in the direction of European political integration. Given the rising Euroscepticism this centralization of the budgetary and fiscal policies of the EU will be difficult to achieve (The Euro Area Crisis 2012, §§ 65-70).

The recent organizational developments are existentially relevant for the everyday life of the citizens in the European Union (Allen, Carletti, Corsetti 2011). One may be struck by the fact that the citizens have not been involved in the important decisions in whatever way (Collignon 2010). The issue does not concern the isolation of voters from the organizational decision-making and control alone. Even national politicians like the members of the Greek parliament stood under the immense pressure to accept policies which have been designed and decided outside of the country. Another sensitive issue is related to the handling of the risks by austerity measures predominantly. Experts consider the fostering of private demand potentially more efficient since economic growth is the only solution to the fiscal troubles in the long run (Blanchard 2011: XIII). In addition, austerity measures are the way of socializing risks. However, there are identifiable individuals, groups and organizations having substantially profited from the policies which caused the risks. The same individuals, groups and organizations have privatized the profits but usually remain least hit by the austerity measures socializing the risks. How far this pattern of risk management corresponds to the expectations for social justice - this is open for further debates. 


\section{CONCLUSIONS}

The application of the differentiated analytical concept of risk in the study of the sovereign debt crisis in the Eurozone turns out to be productive in two respects. First, the concept proves to be efficient for analytical decomposition of complex and dynamic situations. Second, the decomposition opens the way for systematic substantive analyses and conclusions. Following this second line of analyses the sovereign debt crisis in the Eurozone provides sociologists with the example of delayed, hesitant and later panic driven activities for upgrading the rationality of the most advanced macro-regional integration scheme. The crucial turn in this direction is the de facto establishment of European Treasury. The upgrading of the rationality of the European integration has been undertaken under the pressure of circumstances and in an ad hoc manner. This is an indicator for deficits of strategic visions concerning the development of the supranational integration scheme. Nevertheless, the actions undertaken prevented the explosion of organizational disarray in the Eurozone and beyond its boundaries. This conclusion is particularly relevant since we witness a growing number, variety and importance of macro-regional organizations trying to copy best practices from the EU.

The sovereign debt crisis in the Eurozone has very much to do with organizational irrationalities which were in-built in the European Economic and Monetary Union. It has no democratically legitimated body designed for timely and efficient identifying of emerging risks and for fast and adequate decisions and actions. The major reason for this is trivial. The national governments depend on their national constituencies. This status quo has so far prevented the upgrading of organizational rationality by completing the advanced economic integration in the European Union with corresponding political integration. Being an organizational achievement in itself, the permanent European Stability Mechanism is still mostly focused on mitigating the effects of these organizational inefficiencies but not on radically eliminating them. For this latter purpose sophisticated political integration in the European Union is needed for regulating the financial flows in the Union. Otherwise the perpetuated international economic imbalances will continue to reproduce risk situations similar to the Greek sovereign debt crisis. The strategic direction for handling the issue is clear. The domestic demand in the trade surplus running countries should be fostered, while the opposite should be the case in the national economies running trade deficits. Only common institutions could implement this type of concerted action. They will have to carry out the step by step integration in the wage and taxation policies as well as in the social policies. 
The introduction of the European Stability Mechanism is an organizational achievement but it raises fundamental questions: Which groups or which states would profit most from the concerted efforts for balancing the national economies in the European Union? Which groups and which states are going to lose most? The issue is complicated since the balancing of the international financial flows cannot be an internal task of the European Union alone. Global regulation mechanisms are needed in order to avoid deep recessions like the global crisis after 2008. These mechanisms have not been invented and applied yet. This is indicative for the difficulties in balancing prospects to gain or lose due to the global regulation of financial flows.

Still another lesson from the handling of the Greek sovereign debt is related to the identification and handling of responsibilities. Who is actually responsible for the risk situations related to the sovereign debt crisis and has to be punished for them? The population of Greece was victimized by the austerity measures. Is the population of the country the actor who brought about the crisis? One may argue in this direction by referring to work habits, consumption patterns, etc. But the decisions to strategically follow them have been taken by politicians. These decisions have been supported by international lenders. So, who are the actors to be blamed for the risk situation and for its handling by means of austerity measures? The question is related to the obvious need to change organizational patterns leading to massive injustice.

The most important lesson from the above discussions concerns the need to react to the Eurozone crisis by fostering economic growth (Carlin 2011: 9). The simple truth is that efficient budget consolidation is only possible under the conditions of economic growth. The crucial issue concerns the fostering of economic growth in countries which are particularly hit by the sovereign debt crisis and go through economic recession in the same time. The resolving of this double sided crisis by joint efforts is the test for the efficiency of the European solidarity. Carefully designed and implemented policy of Eurobonds could probably become a pillar for strengthening this solidarity. Without it the European integration might run to more and more intensive risks.

How could European solidarity be strengthened under the conditions of widespread Eurosceptic feelings and policies? The answers should be given in the local contexts. The local answers might be only persuasive and mobilizing enough if the European integration can show success in resolving local issues. The mastering of this task requires imagination, rational calculation and decisive action. It would be a challenging and promising research task to comparatively analyze the sequences of efforts to manage the dynamics of risk situations by further applying the analytical concept of risk. 


\section{REFERENCES}

Allen F., Carletti E. and Corsetti G. (eds.) (2011), Life in the Eurozone with or without Sovereign Default? Florence: European University Institute.

Andini C., Cabral R. (2012), Further Austerity and Wage Cuts Will Worsen the Euro Crisis, Bonn: IZA, http://ftp.iza.org/pp37.pdf (30.04.2012).

Arestis P., Sawyer M. (eds.) (2012), The Euro Crisis, Basingstock: Palgrave Macmillan.

Bastasin C. (2012), Saving Europe: How National Politics nearly Destroyed the Euro, Washington, D.C.: Brookings Institution.

Beblavý M. (ed.) (2011), The Euro Area and the Financial Crisis, Cambridge: Cambridge University Press.

Blanchard O. (2011), Foreword, [in:] World Economic Outlook, September. Slowing Growth, Rising Risks, Washington, DC: International Monetary Fund.

Busch K., Hirschel D. (2011), Europe at the Crossroads. Ways Out of the Crisis, Berlin Friedrich-Ebert-Stiftung.

Carlin W. (2011), 10 Questions on the Crisis in the Eurozone, London: University College, http:// www.ucl.ac.uk/european-institute/comment_analysis/eurozone (30.04.2012).

Collignon S. (2010), Democratic Requirements for a European Economic Government, Berlin Friedrich-Ebert-Stiftung.

Delpla J., von Weizsäcker J. (2011), Das Blue Bond-Konzept und seine Implikationen, Berlin Friedrich-Ebert-Stiftung.

The Euro Area Crisis (2012), London: UK Parliament, European Union Committee, TwentyFifth Report, http://www.publications.parliament.uk/pa/ld201012/ldselect/ldeucom/260/26002.htm (29.04.2012).

Genov N. (1999), Managing Transformations in Eastern Europe, Paris: UNESCO/ MOST.

De Grauwe P. (2011), 'What Kind of Governance for the Eurozone?', [in:] W. Meeusen (ed.), The Economic Crisis and European Integration, Cheltenham, UK; Northampton, Mass.: Edward Elgar.

Haller M. (2012), Values and Interests in Processes of Macro-Regional Integration, [in:] N. Genov (ed.) Global Trends and Regional Development, New York: Routledge.

Lorca-Susino M. (2010), The Euro in the 21st Century: Economic Crisis and Financial Uproar, Farnham, UK and Burlington, VT: Ashgate.

Lynn M. (2010), Bust: Greece, the Euro and the Sovereign Debt Crisis, New York: Willey.

Manolopoulos J. (2011), Greece's 'Odious'Debt: The Looting of the Hellenic Republic by the Euro, the Political Elite and the Investment Community, London: Anthem Press.

Mundell R.A. (1968), International Economics, New York: Macmillan.

Renn O. (2008), Risk Governance: Coping with Uncertainty in a Complex World, London: Earthscan.

Riet A. van (ed.) (2010), Euro Area Fiscal Policies and the Crisis, European Central Bank: Frankfurt am Main. 
Nikolai Genov

\title{
ASPEKTY STRUKTURALNE I OGRANICZENIA MODERNIZACJI RACJONALNOŚCI ORGANIZACYJNEJ W DOBIE KRYZYSU W STREFIE EURO
}

\author{
(streszczenie)
}

Kryzys strefy euro związany z narastaniem długu publicznego tworzy szansę na przetestowanie poznawczej i praktycznej adekwatności pewnych ram konceptualnych. W niniejszym artykule przedmiotem testu jest analityczna koncepcja struktury i dynamiki sytuacji ryzykownych. Przewodnia hipoteza wskazuje, że koncept ten może ułatwić systematyczną dekompozycję warunków i działań w trakcie radzenia sobie z kryzysem. Są one zróżnicowane wedle etapów i specyficznych działań dotyczących zarządzania ryzykiem. Analizowane etapy obejmują identyfikację ryzyka, poszukiwanie przyczyn, szacowanie ryzyka, reakcje na ryzyko (zarządzanie ryzykiem) oraz ich ewaluację.

W analizie rozróżnia się wewnętrzne (narodowe i regionalne) oraz zewnętrzne (globalne), ekonomiczne i polityczne, organizacyjne i kulturowe determinanty struktury i dynamiki opisywanej sytuacji ryzyka. Zasadnicze wnioski dotyczą organizacyjnych nieracjonalności wbudowanej w konstrukcję Europejskiej Unii Monetarnej i widoczne w jej funkcjonowaniu. Wartością dodaną podejścia aplikacyjnego do kryzysu strefy euro jest konceptualna integracja opisów, wyjaśnień i prognoz podejmowanych prób zarządzania ryzykiem. Ta konceptualna integracja otwiera możliwości komparatystycznego badania zarządzania ryzykiem w sekwencjach czasowych. 